\title{
RESPONS PASIEN PERILAKU KEKERASAN
}

\author{
Titik Suerni ${ }^{1}$, Livana $\mathbf{P H}^{2 *}$ \\ ${ }^{1}$ RSJD Dr. Amino Gondohutomo Provinsi Jawa Tengah, Jl. Brigjen Sudiarto No.347, Gemah, Kec. Pedurungan, \\ Kota Semarang, Jawa Tengah, Indonesia 50246 \\ ${ }^{2}$ Program Studi Sarjana Keperawatan, Sekolah Tinggi Ilmu Kesehatan Kendal, J1. Laut 31A Ngilir Kendal, Jawa \\ Tengah, Indonesia 51311 \\ *livana.ph@gmail.com (+6289667888978)
}

\begin{abstract}
ABSTRAK
Perilaku kekerasan yang terjadi pada pasien gangguan jiwa memiliki batasan karakteristik yang berbeda-beda. Penelitian ini bertujuan untuk mengetahui respons pasien dengan resiko perilaku kekerasan. Penelitian ini merupakan penelitian kuantitatif dengan rancangan penelitian deskriptif dan pendekatan survey. Sampel penelitian ini adalah pasien yang mempunyai masalah keperawatan prilaku kekerasan diruang Madrim RSJD Dr. Amino Gondhohutomo Provinsi Jawa Tengah yang berjumlah 20 orang. Data dianalisis secara univariat berupa distribusi frekuensi. Hasil penelitian menunjukkan bahwa mayoritas responden berrespons kognitif berupa perubahan isi pikir dan menyalahkan orang lain, respons afektif berupa perasaan tidak nyaman, respons fisiolofis berupa pandangan tajam dan tangan mengepal, respons perilaku berupa memukul benda/ orang dan agresif, respons sosial berupa sering mengungkapkan keinginannya dengan nada mengancam. Perlu intervensi keperawatan yang tepat untuk mengurangi respons kognitif, afektif, fisiologi, perilaku, sosial pada pasien perilaku kekerasan.
\end{abstract}

Kata kunci: respons pasien, resiko perilaku kekerasan

\section{IMPROVEMENT OF CADER KNOWLEDGE ABOUT EARLY DETECTION OF SOUL HEALTH THROUGH MENTAL HEALTH EDUCATION}

\begin{abstract}
Violent behavior that occurs in patients with mental disorders have different characteristics limits. This study aims to determine responses in patients at risk of violent behavior. This research is a quantitative study with a descriptive research design and survey approach. The sample of this study were patients who had nursing problems of violent behavior in Madrim Hospital Dr. Amino Gondhohutomo, Central Java Province, amounting to 20 people. Data were analyzed univariately in the form of frequency distributions. The results showed that the majority of respondents responded cognitively in the form of changes in thought content and blaming others, affective responses in the form of uncomfortable feelings, physiological responses in the form of sharp eyes and clenched fists, behavioral responses in the form of hitting objects / people and aggressively, social responses in the form of often expressing their desires with threatening tone. Need appropriate nursing intervention to reduce cognitive, affective, physiological, behavioral, social responses in violent behavior patients.
\end{abstract}

Keywords: patient response, risk of violent behavior

\section{PENDAHULUAN}

Perilaku kekerasan merupakan suatu kemarahan yang diekspresikan oleh individu secara berlebihan sehingga tidak dapat dikendalikan baik secara verbal maupun non dan dapat mencederai diri, orang lain serta merusak lingkungan (Depkes, 2007). Perilaku kekerasan dapat disebabkan oleh beberapa faktor baik faktor predisposisi ataupun presipitasi yang keduanya dapat memicu terjadinya perilaku kekerasan. Perilaku kekerasan terjadi karena adanya hasil akumulasi frustasi yang berulang dan dikarenakan keinginan individu yang tidak tercapai atau bahkan gagal, sehingga individu berperilaku 
agresif. Menurut Keliat (2005) ada beberapa tanda gejala terjadinya perilaku kekerasan diantaranya yaitu, bicara kasar, muka merah, otot tegang, pandangan tajam, berdebat, nada suara tinggi, memaksakan kehendak seperti merampas makanan dan memukul jika menemui hal-hal yang tidak disenangi.

Data WHO (2015)menunjukkan bahwa prevalensi pasien gangguan jiwa mencapai hampir 450 juta orang, dimana sepertiganya berada di negara berkembang. Indonesia merupakan salah satu negara yang memiliki Sedangkan di Indonesia, hasil Riskesdas (2018) menyebutkan bahwa prevalensi gangguan mental emosional yang ditunjukkan dengan gejala-gejala gangguan jiwa berat, seperti schizophrenia adalah terjadi peningkatan dari 1,7 persen pada tahun 2013 dan meningkat menjadi 7 persen (Kemenkes, 2014). Di Provinsi jawa tengah kunjungan pasien gangguan jiwa sebanyak 260.247 orang (Dinas Kesehatan Provinsi Jawa Tengah, 2014). Hasil studi pendahuluan yang dilakukan di Ruang Madrim RSJD Amino Gondohutomo Provinsi Jawa Tengah didapatkan bahwa mayoritas diagnosis keperawatan yang muncul selama 3 bulan terakhir adalah resiko perilaku. Berdasarkan latar belakang tersebut perlu dilakukan penelitian terkait respons kognitif, afektif, fisiologi, perilaku, dan sosial pada pasien resiko perilaku kekerasan di RSJD Amino Gondohutomo Provinsi Jawa Tengah.

\section{METODE}

Penelitian kuantitatif menggunakan rancangan penelitian deskriptif dengan pendekatan survei yaitu penelitian yang dilakukan untuk mendiskripsikan respons kognitif, afektif, fisiologi, perilaku, dan sosial pasien dengan perilaku kekerasan. Populasi dalam penelitian ini adalah semua pasien di ruang Madrim yang muncul diagnosis prilaku kekerasan di RSJD Dr. Amino Gondhohutomo provinsi jawa tengah. Cara mengambil sampel menggunakan metode total Sampling. Jumlah sampel yaitu 20 orang. Penelitian dilaksanakan pada bulan Februari 2019. Data dianalisis secara univariat berupa distribusi frekuensi.

\section{HASIL}

Hasil penelitian terkait respons pasien disajikan pada tabel berikut.

Tabel 1.

Respons kognitif pasien perilaku kekerasan $(n=20)$

\begin{tabular}{|c|c|c|}
\hline \multirow[t]{2}{*}{ Tanda dan gejala } & \multicolumn{2}{|c|}{ Hari ke 1-2 } \\
\hline & $f$ & $\%$ \\
\hline \multicolumn{3}{|l|}{ Subjektif } \\
\hline Mengungkapkan ketidakmampuan mengontrol PK & 19 & 95 \\
\hline Merasa berpikir negative dalam menghadapi stressor & 15 & 75 \\
\hline Mengungkapkan keinginan untuk memukul orang lain & 17 & 85 \\
\hline Mengungkapkan ketidakmampuan dalam berkomunikasi & 15 & 75 \\
\hline \multicolumn{3}{|l|}{ Objektif } \\
\hline \multicolumn{3}{|l|}{ Mendominasi pembicaraan } \\
\hline Flight of idea & 17 & 85 \\
\hline Perubahan isi pikir & 20 & 100 \\
\hline Menyalahkan orang lain & 20 & 100 \\
\hline Kurang konsentrasi & 19 & 95 \\
\hline Mudah putus asa & 13 & 65 \\
\hline Kepribadian tertutup & 16 & 80 \\
\hline Agresif & 6 & 30 \\
\hline
\end{tabular}

Tabel 1 menunjukkan bahwa mayoritas hingga ke 2 pada pasien perilaku kekerasan respons kognitif yang muncul hai ke 1 secara subyektif mengungkapkan 
ketidakmampuannya mengontrol perilaku kekerasan sedangkan secara obyektif mayoritas responden terjadi perubahan isi pikir dan menyalahkan orang lain.

Tabel 2.

Respons afektif pasien perilaku kekerasan $(n=20)$

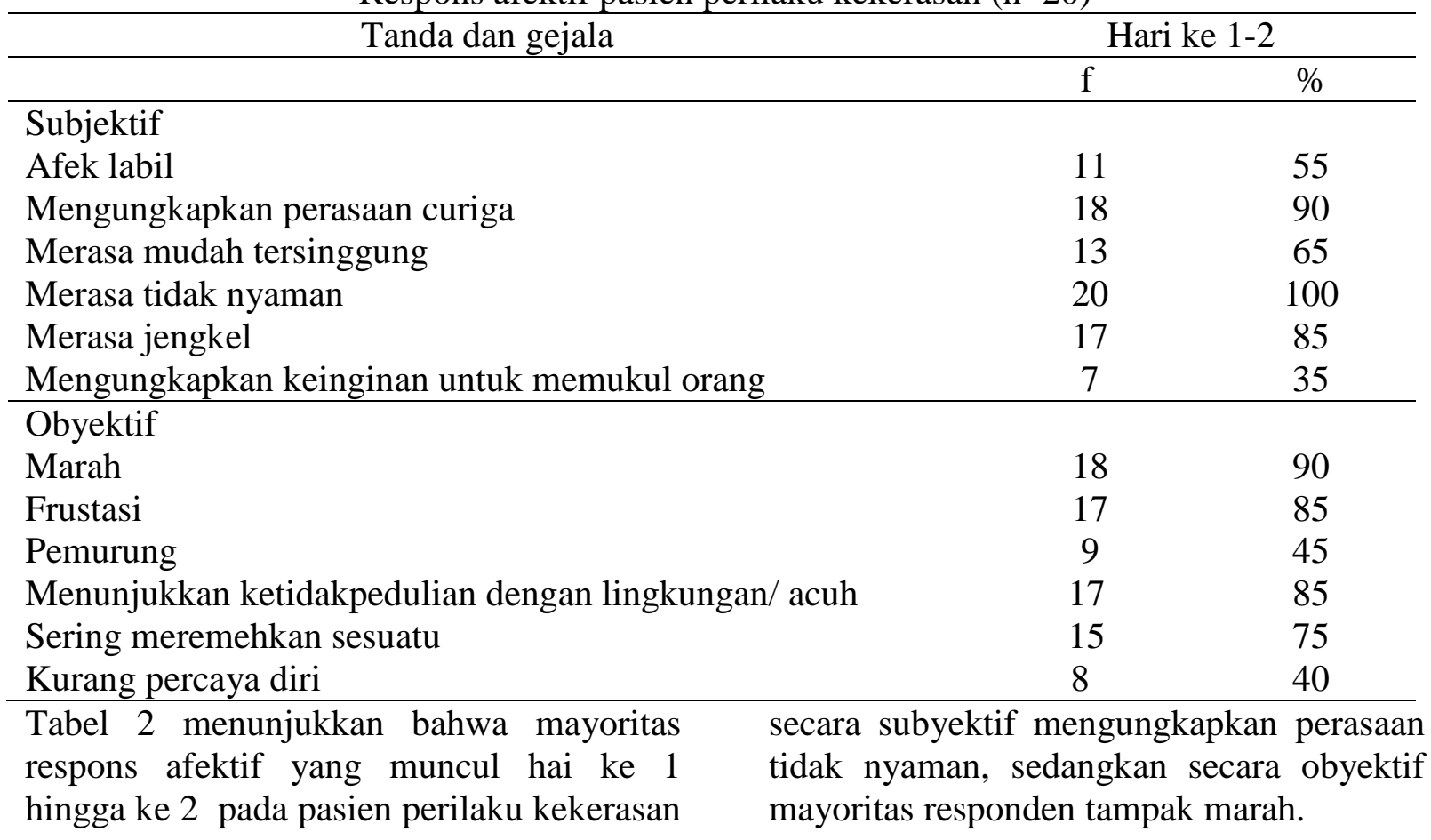

Tabel 3.

Respons fisiologi pasien perilaku kekerasan $(n=20)$

\begin{tabular}{|c|c|}
\hline \multirow[t]{2}{*}{ Tanda dan gejala } & $1-2$ \\
\hline & $\%$ \\
\hline \multicolumn{2}{|l|}{ Subjektif } \\
\hline Mengatakan pusing & 17 \\
\hline Merasa berdebar-debar & 18 \\
\hline Mengungkapkan keluhan mual, tidak enak di perut & 18 \\
\hline \multicolumn{2}{|l|}{ Obyektif } \\
\hline Muka merah & 17 \\
\hline Pandangan tajam & 20 \\
\hline Rahang mengatup dengan kuat & 18 \\
\hline Tangan mengepal & 20 \\
\hline Wajah tegang dan kewaspadaan meningkat & 1 \\
\hline $\begin{array}{l}\text { Tabel } 3 \text { menunjukkan bahwa mayoritas } \\
\text { respons fisiologis yang muncul hai ke } 1 \\
\text { hingga ke } 2 \text { pada pasien perilaku kekerasan } \\
\text { secara subyektif merasa berdebar-debar dan } \\
\text { merasa mual serta tidak enak di perut, } \\
\text { sedangkan secara obyektif mayoritas } \\
\text { responden tampak pandangan tajam dan } \\
\text { tangan mengepal. }\end{array}$ & $\begin{array}{l}\text { Tabel } 4 \text { menunjukkan bahwa mayoritas } \\
\text { respons perilaku yang muncul hai ke } 1 \\
\text { hingga ke } 2 \text { pada pasien perilaku kekerasan } \\
\text { secara subyektif mengungkapkan selalu } \\
\text { curiga, sedangkan secara obyektif merusak } \\
\text { benda/ menciderai orang lain serta } \\
\text { berperilaku agresif. }\end{array}$ \\
\hline
\end{tabular}

Tabel 5 menunjukkan bahwa mayoritas respons sosial yang muncul hai ke 1 hingga 
ke 2 pada pasien perilaku kekerasan secara subyektif mengungkapkan keinginannya dengan nada mengancam, sedangkan secara obyektif mayoritas responden mengasingkan diri.

Tabel 4.

Respons perilaku pasien perilaku kekerasan $(n=20)$

Tanda dan gejala Hari ke $1-2$

$\mathrm{f} \%$

\section{Subjektif}

Mengatakan selalu curiga

Mengungkapkan keinginan untuk melukai diri sendiri/ orang

lain

Obyektif

Mondar-mandir

Memukul benda/ orang

Merusak barang

Nada suara tinggi/ keras

Agresif

Suka membentak orang lain

Tabel 5.

Respons sosial pasien perilaku kekerasan $(n=20)$

\begin{tabular}{lc}
\hline \multicolumn{1}{c}{ Tanda dan gejala } & Hari ke 1-2 \\
\hline Subjektif & f $\%$ \\
Sering mengungkapkan keinginannya dengan nada mengancam & 20 \\
Secara verbal sering mengejek, mengolok-olok & 15 \\
\hline Obyektif & \\
Menarik diri dalam pergaulan lingkungan sekitar & 17 \\
Mengasingkan diri & 19 \\
Penolakan & 3 \\
\hline
\end{tabular}

\section{PEMBAHASAN}

Hasil penelitian menunjukkan bahwa mayoritas responden menunjukkan respons kognitif berupa perubahan isi pikir dan menyalahkan orang lain. Respons tersebut juga merupakan salah satu faktor yang menyebabkan pasien dirawat di RSJ. Hasil penelitian ini sesuai dengan penelitian Hidayati (2012) bahwa perilaku kekerasan merupakan kasus yang paling banyak terjadi di RSJ sehingga keluarga memutuskan untuk merawat klien di RSJ.

Tabel 2 menunjukkan bahwa mayoritas responden mengungkapkan perasaan tidak nyaman dan menunjukkannya dengan marah. Respons tersebut terjadi karena keinginannya tidak terpeuhi, sehingga keluarga sebagai orang terdekat pasien hendaknya dapat berupaya untuk mengatasi ataupun mencegah agar respons marah dapat dihindari yaitu dengan memenuhi keinginan pasien. Hasil penelitian ini sejalan dengan penelitian Wuryaningsih dan Hamid (2013) bahwa salah satu upaya untuk mengendalikan marah pasien dilakukan keluarga melalui sikap permisif kepada pasien seperti menuruti keinginan pasien dan membiarkan pasien melakukan apapun yang diinginkan oleh pasien. 
Tabel 3 menunjukkan bahwa mayoritas responden memiliki respons fisiologis dengan tangan mengepal dan pandangan tajam. Hasil ini sejalan dengan penelitian Pratama (2012) bahwa salah satu dari beberapa tanda pasien marah yaitu tangan mengepal. Penelitian Mariyati, Hamid, Daulima (2018) menunjukkan bahwa dampak fisik dan psikososial dari penggunaan pembatasan keinginan pasien gangguan jiwa dapat ditunjukkan dengan perilaku agresif sebagai salah satu alasan utama menahan diri.

Tabel 4 menunjukkan mayoritas responden memiliki respons perilaku berupa perasaan curiga, merusak alat, dan menciderai orang lain. Hasil ini sejalan dengan hasil penelitian Mats, Joakim, Henrik, Marianne (2017). bahwa individu yang memiliki ide kekerasan dalam hidup mereka secara signifikan lebih rentan untuk melakukan tindakan kekerasan.

Tabel 5 menunjukkan bahwa pasien perilaku kekerasan memiliki respons sosial ditunjukkan dengan sikap yang sering mengasingkan diri ataupun mengungkapkan keinginan dengan nada mengancam. Hasil ini sesuai dengan penlitian Leslie, Kristie, Thomas, Michael, Joanna, Lori, White, Waldam (2019) bahwa kontrol lingkungan sosial yang rendah memicu terjadinya perilaku kekerasan.

\section{SIMPULAN}

Mayoritas responden berrespons kognitif berupa perubahan isi pikir dan menyalahkan orang lain, respons afektif berupa perasaan tidak nyaman, respons fisiolofis berupa pandangan tajam dan tangan mengepal, respons perilaku berupa memukul benda/ orang dan agresif, respons sosial berupa sering mengungkapkan keinginannya dengan nada mengancam

\section{DAFTAR PUSTAKA}

Depkes RI. ( 2007 ). Standart Asuhan Keperawatan Jiwa. Magelang RSJ Prof. Dr. Soeroyo Magelang.
Dinkes Provinsi Jawa Tengah, (2014). Profil Kesehatan Provinsi Jawa Tengah Tahun 2014. Hal 102. Diakses tanggal 1 April 2019. darihttp://www.dinkesjatengprov.go.i d/v2015/dokumen/profil2014/Profil_2 014.pdf

Hidayati, E. (2012). Pengaruh Terapi Kelompok Suportif terhadap Kemampuan Mengatasi Perilaku Kekerasan pada Klien Skizofrenia Di Rumah Sakit Jiwa Dr. Amino Gondohutomo Kota Semarang. In PROSIDING SEMINAR NASIONAL INTERNASIONAL (Vol. 1, No. 1).

http://rs-

amino.jatengprov.go.id/?q=content/la poran-10-besar-penyakit

Keliat. ( 2005 ). Proses Keperawatan Kesehatan Jiwa (terjemahan). Jakarta EGC.

Leslie J. Sattler, Kristie A. Thomas, Michael G. Vaughn, Joanna Almeida, Lori A. White, Marcus R. Waldman. (2019) Community matters: GxE interactions predicting childhood aggression and violent behavior, Journal of Criminal Justice, Volume 61,2019, Pages 58-71,ISSN 00472352 ,

https://doi.org/10.1016/j.jcrimjus.201 9.03.002.(http://www.sciencedirect.co $\mathrm{m} / \mathrm{science} /$ article/pii/S004723521930 0339)

Mariyati Achir Yani Syuhaimie Hamid, Novy Helena Catharina Daulima, (2018). The experience of restraintuse among patients with violent behaviors in mental health hospital, Enfermería Clínica,Volume 28, Supplement 1,2018,Pages 295-299, ISSN $1130-$

8621,https://doi.org/10.1016/S11308621(18)30173-

6.(http://www.sciencedirect.com/scie nce/article/pii/S1130862118301736) 
Mats Persson, Joakim Sturup, Henrik Belfrage, Marianne Kristiansson. (2017). Self-reported violent ideation and its link to interpersonal violence among offenders with mental disorders and general psychiatric patients, Psychiatry Research, Volume 261, 2018, Pages 197-203, ISSN 0165-1781, https://doi.org/10.1016/j.psychres.201 7.12.079.(http://www.sciencedirect.co $\mathrm{m} / \mathrm{science} /$ article/pii/S016517811730 5358)

PRATAMA, S. A. (2012). Asuhan Keperawatan Pada Sdr. Y Dengan Gangguan Perilaku Kekerasan Di Ruang Amarta Rumah Sakit Jiwa Daerah Surakarta (Doctoral dissertation, Universitas Muhammadiyah Surakarta).

RSJD Dr. Amino Gondohutomo Semarang Prov. Jateng, (2016). Laporan 10 Besar Penyakit. Diakses tanggal 29 Maret 2018 dari

WHO, (2015). Mental Disorders. Diakses tanggal 28 Maret 2016 darihttp://www.who.int/mediacentre/f actsheets/fs396/en/

Wuryaningsih, E. W., \& Hamid, A. Y. S. (2013). Studi Fenomenologi: Pengalaman Keluarga Mencegah Kekambuhan Perilaku Kekerasan Pasien Pasca Hospitalisasi RSJ. Jurnal Keperawatan Jiwa, 1(2). 